\title{
NICKEL PROSPECTIVE MODELLING USING FUZZY LOGIC ON NOVA BRASILÂNDIA METASEDIMENTARY BELT, RONDÔNIA, BRAZIL
}

\author{
Lucas Barros de Andrade ${ }^{1,3}$, Adalene Moreira Silva² and Carlos Roberto de Souza Filho ${ }^{3}$
}

\begin{abstract}
Multisource spatial data integration represents a common tool in mineral prospecting, especially with the advent of Geographic Information Systems (GIS), which allow manipulation, interpretation, analysis, integration and modelling of spatial data. The Nova Brasilândia Metasedimentary Belt (NBMB), located in SW Amazonian craton, is part of a geological context with considerable metallogenic potential for base metals, although significant deposits are not known yet. The present paper aimed to process aeromagnetometry and aerogammaspectrometry data for integration with geochemical and geological mapping campaigns in order to build a prospectivity model for nickel in the NBMB region of in a 1:500,000 scale. Using knowledge-driven approach modelling, fuzzy logic was chosen to combine geophysics, geochemistry and geological mapping data. As result, it was possible to build a prospectivity model for nickel, consistent with the distribution of nickel occurrences registered by the Geological Survey of Brazil (Serviço Geológico do Brasil - CPRM), and which may guide detailed prospecting campaigns in the region.
\end{abstract}

Keywords: airborne geophysics, fuzzy logic, prospective modelling, metasedimentary belt, Nova Brasilândia.

RESUMO. A integração de dados espaciais multifontes é ferramenta consagrada na prospecção mineral, especialmente com o advento dos Sistemas de Informações Georreferenciadas (SIG), que permitem a manipulação, interpretação, análise, integração e modelagem de dados espaciais. 0 Cinturão Metassedimentar Nova Brasilândia (CMNB), situado no SW do cráton amazônico, insere-se em contexto geológico com considerável potencial metalogenético para metais básicos, ainda que depósitos expressivos não sejam conhecidos. 0 presente trabalho teve por objetivo processar dados de aeromagnetometria e aerogamaespectrometria para integração de dados de campanhas de prospecção geoquímica e mapeamento geológico regionais a fim de construir um modelo de prospectividade para níquel na região do CMNB em escala 1:500.000. Foi adotada a abordagem guiada pelo conhecimento para a modelagem proposta, utilizando-se lógica fuzzy para combinar dados de geofísica, geoquímica e mapeamento geológico. Como resultado, foi possível construir um modelo de prospectividade para níquel, compatível com a distribuição de ocorrências cadastradas pelo Serviço Geológico do Brasil (CPRM), que pode nortear campanhas de prospecção de maior detalhe na região.

Palavras-chave: aerogeofísica, lógica fuzzy, modelagem prospectiva, cinturão metassedimentar, Nova Brasilândia.

\footnotetext{
1 Departamento de Polícia Federal, Unidade Técnico Científica da Delegacia de Polícia Federal em Marília/SP, Av. Jóquei Clube, 87, Bairro Jóquei Clube, 17521-450 Marília, SP, Brazil. Phone: +55(14) 3303-3033; Fax: +55(14) 3303-3031 - E-mail: lucas.lba@dpf.gov.br

2Universidade de Brasília, Instituto de Geociências, Campus Universitário Darcy Ribeiro s/n, 70910-900 Brasília, DF, Brazil. Phone: +55(61) 3307-2877; Fax: +55(61) 3340-4759 - E-mail: adalene@unb.br

${ }^{3}$ Universidade Estadual de Campinas, Instituto de Geociências, P.0. Box 6152, 13083-970 Campinas, SP, Brazil. Phone: +55(19) 3521-4535; Fax: +55(19) 3521-4552

- E-mail: beto@ige.unicamp.br
} 


\section{INTRODUCTION}

Integration of multisource data as geophysics, geochemistry and remote sensing is a very common tool used in mineral prospection. Initially performed in analog way by overlapping maps in lightboxes, recently significant advances have been reached by the use of Geographic Information Systems (GIS), which allows easier manipulation, interpretation, analysis, integration and modelling of spatial data involving math, logic and probabilistic (Bonham-Carter, 1994, 1997).

The Nova Brasilândia Metasedimentary Belt (NBMB), located in the Southwest of the Amazonian craton, presents considerable metallogenic potential for base metals (Rizotto, 1999), although significant deposits are not known yet. Therefore, corresponds to a Brazilian border where regional exploration works are indicated to select targets for detailed exploration.

This paper aims to process aerogeophysical data of the region NBMB and then integrate these data with stream sediments geochemical surveys and lithological mapping in order to develop, through fuzzy logic, a mineral prospectivity model for nickel (Ni) in the study area on a regional scale $(1: 500,000)$.

\section{GEOLOGIC CONTEXT}

Figure 1 shows the geological map of the study area modified from Schobbenhaus et al. (2004). The regional geological context is related to the boundary between the Rondônia-Juruena and Sunsás Provinces (Santos, 2003), partially covered by Phanerozoic sediments.

The Rondônia-Juruena Province is represented in the study area mainly (i) by Jamari Complex, consisting of felsic to intermediate polycyclic gneisses, metamorphosed and migmatizeds in amphibolite facies, (ii) Serra da Providência Intrusive Suit and (iii) Roosevelt Group, respectively volcanic and plutonic components of the magmatic arc that encloses the tectonic structuration this province (Tohver et al., 2004). The intrusive suits São Romão, formed by metaplutonic high-K calc-alkaline rocks, Alto Candeias, composed by charnokitos and monzo to sieno granitoids, and Cacoal, of basic to ultrabasic nature, are also part of the province, as well as sedimentary rocks of Dardanelos Formation, base of the Caiabis Group (Schobbenhaus et al., 2004).

The Migrantinópolis Formation, essentially composed by metasedimentary rocks, and the White River Formation, of intrusive metabasic nature, are units of the Sunsás Province (Santos, 2003) and locally form the Nova Brasilândia Metasedimentary Belt (NBMB) (Rizzotto, 2001; Tohver et al., 2004). In this belt, numerous signs and occurrences of $\mathrm{Au}, \mathrm{Ni}, \mathrm{Cu}, \mathrm{Cr}$ and $\mathrm{Pt}$ are cataloged by the Geological Survey of Brazil (Serviço Geológico do Brasil - CPRM) (Schobbenhaus et al., 2004). However, except for some artisanal gold mining, more expressive metallic deposits still unknown.

Granites of the Rio Pardo Intrusive Suit occur as oval bodies concordant with the foliation of host rocks and mark the end of the orogenic cycle that affected the NBMB in the Esteniano-Tonian limit (Scandolara, 1999; Rizzotto, 1999).

The Alta Floresta Intrusive Suit comprises a combination of basic rocks, which occurs as hectametric sills (Scandolara, 1999) and may be related to a later distensive stage in the Mesoproterozoic orogeny (Rizzotto, 1999). The Costa Marques Intrusive Suit consists of subvolcanic granites, granofires, rhyolites, rhyodacites, trachytes and lamprophyres dykes occurring as ellipsoidal to circular stocks (Scandolara, 1999). Teixeira and Tassinari (1984) obtained ages of $1018 \pm 76 \mathrm{Ma}$ for these rocks and suggest a correlation with the Younger Granites of Rondônia of Kloosterman (1968).

Many Neoproterozoic and Phanerozoic sedimentary units overlays older rocks in the SW Amazonian craton (Tohver et al., 2004). The oldest of them is the Palmeiral Formation, deposited in the Rondônia Basin, formed in the Pacaás Novos, Upioanes and St. Lawrence grabens (Scandolara, 1999). An expressive package of Paleozoic sedimentary rocks, deposited mainly in grabens directed WNW-ESSE (Pimenta Bueno Graben and Parecis Graben), comprise the Primavera Group, which includes Rio Rolim de Moura, Pimenta Bueno and Fazenda da Casa Branca Formations (Scandolara, 1999). The unit lateritic-detritus covers includes varied types of Cenozoic colluvial, eluviais, alluvial, lacustrine and swamp deposits (Rizzotto et al., 2000), beyond lateritic soils.

The structural setting observed in the area reflects the complex polycyclic tectonic evolution which affected the region between the Paleo and Mesoproterozoic. Subparalelism between deformational events and reactivation of older structures difficult the understanding of the geological history of the area.

In the Paleoproterozoic basement of Rondônia-Juruena Province (Santos, 2003), predominate NW shear zones developed during the structuring of Rio Negro Juruena Arc (Tohver et al., 2005).

At the end of the Mesoproterozoic, the development of NBMB was mainly in a sinistral transpressive regime that generated extensive thrusting and dextral shear zones, with vergence to NE in the southern and SW in the northern of the belt (Tohver et al., 2004).

Extensional efforts at the end of the Precambrian were responsible for the extensional reactivation of older structures and 

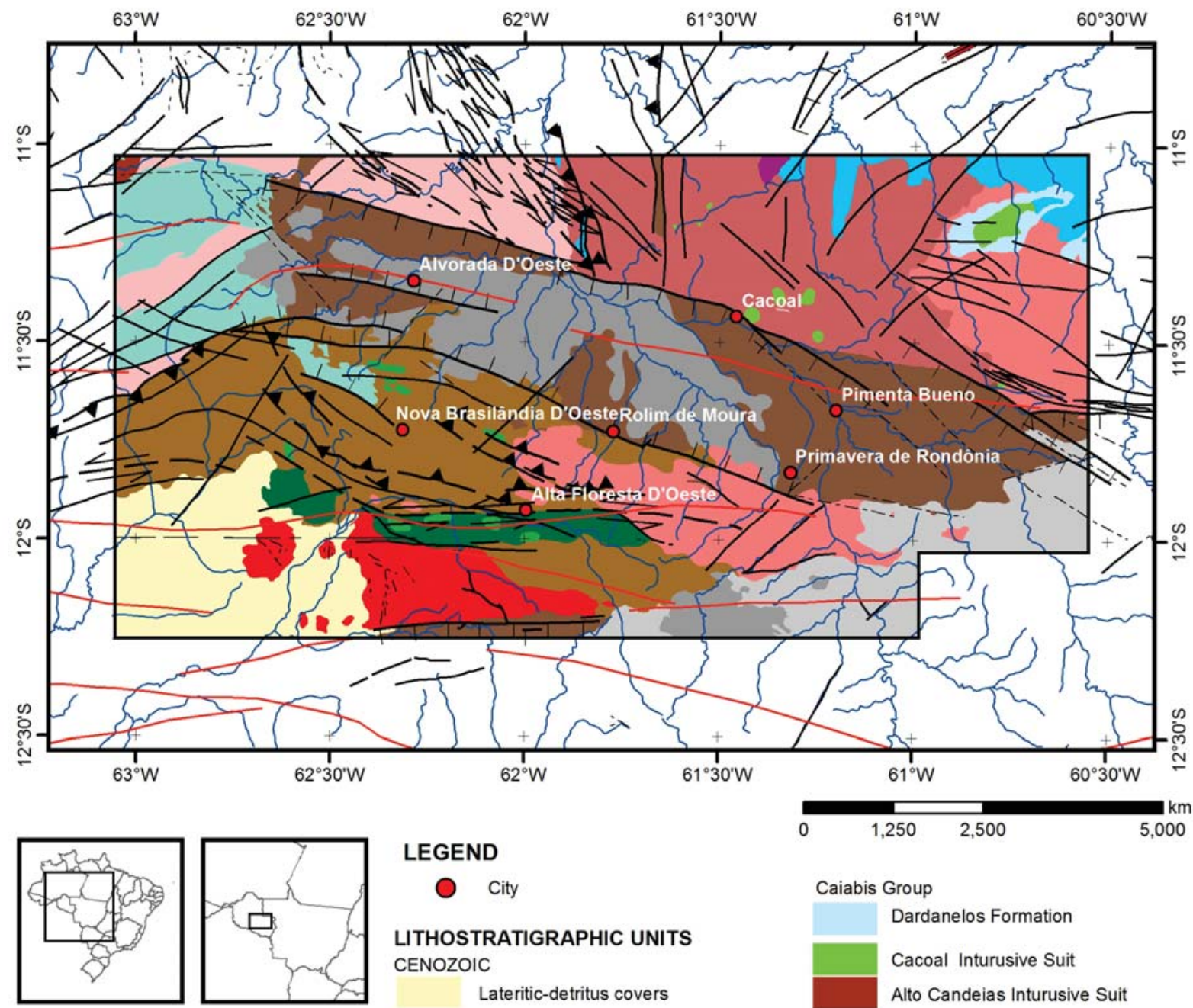

LEGEND

City

LITHOSTRATIGRAPHIC UNITS

CENOZOIC

Lateritic-detritus covers

PALEOZOIC

Primavera Group

Pimenta Bueno Formation

Fazenda da Casa Branca Formation

Rio Rolim de Moura Formation

\section{NEOPROTEROZOIC}

Palmeiral Formation

Costa Marques Intrusive Suit

MESOPROTEROZOIC

Alta Floresta Intrusive Suit

Rio Pardo Intrusive Suit

Nova Brasilândia Group

Migrantinópolis Formation

Rio Branco Formation

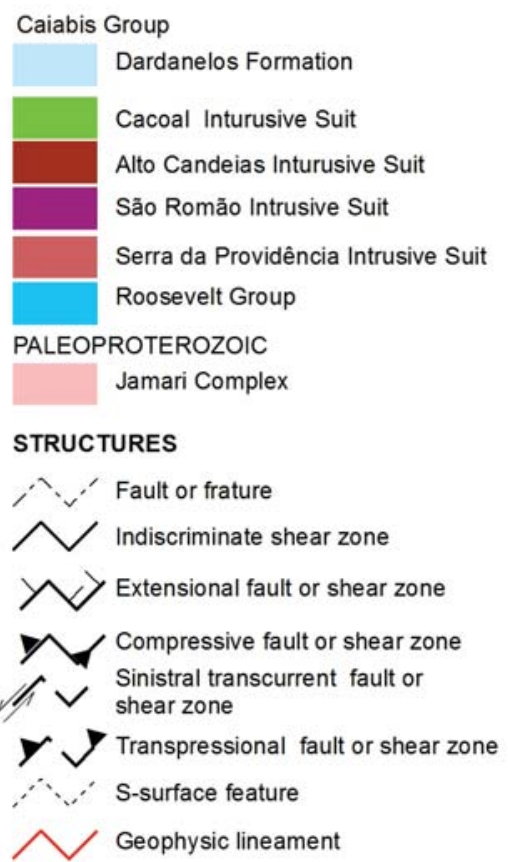

Figure 1 - Geological map of the study area adapted from Schobbenhaus et al. (2004). 
developement of normal faults on a large scale. This distensional phase formed a system of grabens, that includes Pimenta Bueno Graben, which came to be filled in the Phanerozoic.

\section{AEROGEOPHYSICAL DATA}

In this work, the authors used aeromagnetometric and aerogammaespectometry data obtained by Geological Survey of Brazil CPRM at the end of the 70's. The study area is covered by to different surveys: Pacaás Novos Project and Serra dos Parecis Project, performed by GEOFOTO S/A. Table 1 shows the characteristics of both surveys, consistent with the scale proposed $(1: 500,000)$. The raw data were provided by the Geophysics Division of CPRM.

Table 1 - Characteristics of aerogeophysical surveys.

\begin{tabular}{|c|c|c|}
\hline Characteristics & $\begin{array}{c}\text { Pacaás Novos } \\
\text { Project }\end{array}$ & $\begin{array}{c}\text { Serra dos Parecis } \\
\text { Project }\end{array}$ \\
\hline Year & 1978 & 1979 \\
Profiles length $(\mathrm{km})$ & 28,003 & 27,738 \\
Covered area $\left(\mathrm{km}^{2}\right)$ & 49,000 & 48,000 \\
Flight high $(\mathrm{m})$ & 150 & 150 \\
Flight lines direction & $\mathrm{N}-\mathrm{S}$ & $\mathrm{N}-\mathrm{S}$ \\
Flight lines off-set $(\mathrm{km})$ & 2 & 2 \\
Control lines direction & E-W & E-W \\
Control lines off-set $(\mathrm{km})$ & 20 & 18 \\
Gamma integration time $(\mathrm{s})$ & 1 & 1 \\
\hline
\end{tabular}

The magnetometry data were received as anomalous magnetic field values, already corrected IGRF. The gammaspectrometric data were received in separated channels for $K, U$ and Th, in counts per second.

For using geophysical data, it was necessary to perform some pre-processing procedures, as interpolation, microniveling and geophysical surfaces generation, using the Oasis Montaj, Geosoft Inc. software.

Preprocessing steps include the construction of a digital database containing the geophysical data of each block. In this step were corrected (i) spurious peaks in the magnetic data using the methods Fourth Difference and "P" Parameter (Blum, 1999) and (ii) negative values in the gammaspectrometric data by adding the standard deviation value for each channel. Geophysical blocks were jointed using the Grid Knitting algorithm. In this operation, whenever necessary, the algorithm removes an order zero, one or two trend surface, in order to equalize the base level of the grids.

Data interpolation for each block and each channel (magnetometry, gammaspectrometry) was performed after the preprocessing. The interpolation method chosen was the minimum curvature, because its sensitivity to the difference between frequency of sampling between and along the lines of flight. The surfaces generated by interpolating were microniveled (Minty, 1991; Blum, 1999) for subsequent generation of processed products.

The products 1 vertical derivative, horizontal gradient and analytic signal amplitude were generated based on the anomalous magnetic field. Figure 2 shows the analytic signal amplitude map, used in the prospective modelling representing intensity and position of magnetic anomalies.

Gammaspectrometric data are obtained by measuring the gamma radiation emitted by certain elements that compose the various rock types. Gamma radiation measured is proportional to concentration of the elements. Gammaspectrometric data are complementary to the magnetometric products. The magnetic sources on diferent depths contribute to the measured field, while the radiometric data represent only the first 30 to $40 \mathrm{~cm}$ from the surface.

From the data in counts per second (cps), maps were generated for each gammaspectrometric channel: K, U and Th, which were combined in false color ternary compositions for visual analysis.

Figure 3 shows the ternary composition in false color using the CMY color pattern, product that allows better visualization of the correspondence between the geological units and their gammaspectrometric responses.

\section{STREAM SEDIMENTS GEOCHEMICAL DATA}

Interpolated surfaces generated from eight hundred and twenty five (825) samples of stream sediments were used to the construction of the nickel mineral prospectivity model for the NBMB. These samples comprise the collection of Southeast Rondônia Project, conducted by the Geological Survey of Brazil - CPRM (Pinto Filho, 1977).

Although stream sediments concentrations interpolation is cause for controversy in mineral exploration, the use of interpolated surfaces is often necessary to construct models of mineral prospectivity (Andrade, 2008).

Collection, preparation and analysis procedures described by Pinto Filho (1977) were as follows: (i) samples of stream sediments were collected in beds active drainage below the water level, in straight stretches and approximate quantity $1 \mathrm{~kg}$, sieved in fraction $<32$ mesh, (ii) sample preparation followed the routine of air drying in paper bags, sieving in the fraction $<80$ mesh, spraying a 100/150 mesh and total acid digestion (iii) analyzes were then conducted by emission spectrographic technique, also known as optical emission spectrometry. 


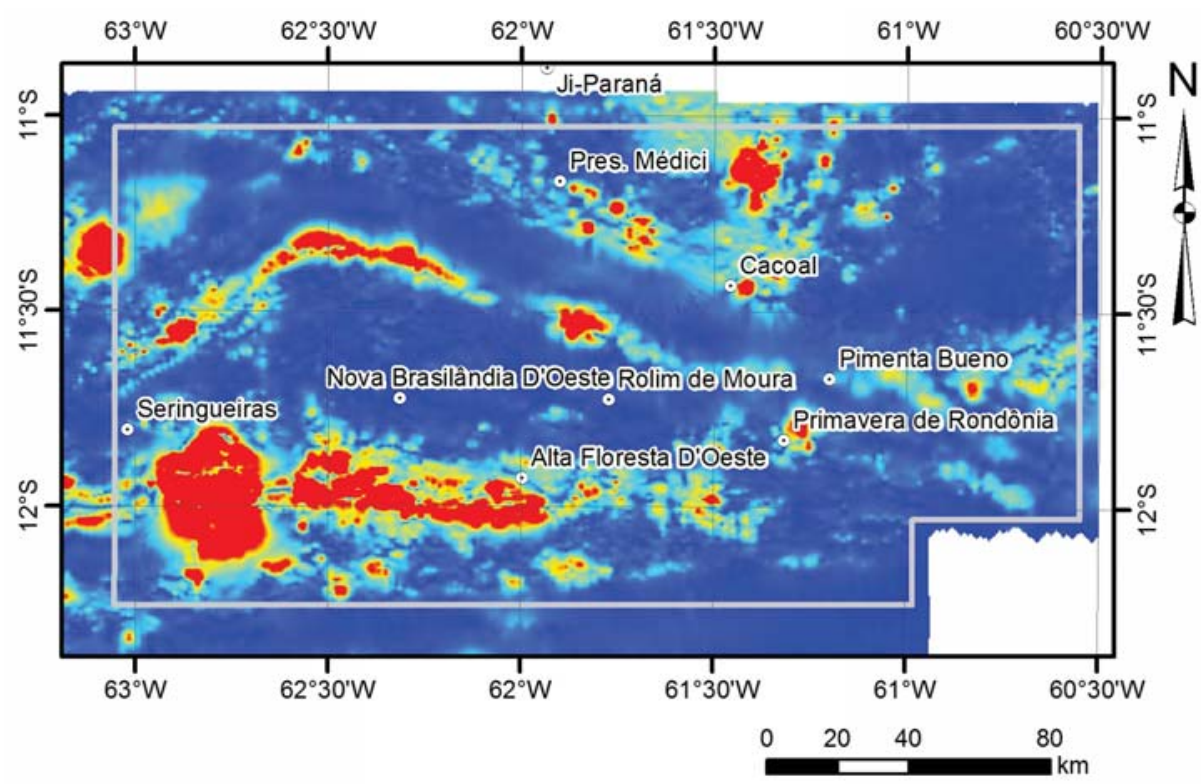

\section{Legend}

\section{Analytical signal amplitude of anomalous magnetic field}

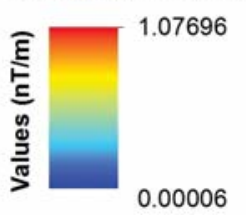

Study area limit

C City

Figure 2 - Analytic signal amplitude map. The high values are positioned on magnetic anomalies sources, associated with basic and/or ultrabasic rocks, structural sutures and sources covered by Phanerozoic rocks and sediments.

Samples with not detected results, below detection limit and with interference were subjected to statistical preprocessing described by Lins (2003) in Technical Handbook of Geochemistry Area of CPRM.

$\mathrm{Ni}$ and $\mathrm{Co}$ analyzes were selected for the study because anomalous concentrations of these elements are commonly associated with base metals mineralizations.

The Inverse Weighting Distance Multifractal, or IDW-Multifractal (Cheng, 1999; Li et al., 2004), was the interpolatory technique chosen. Unlike interpolation by Inverse Distance Weighting, the interpolation by IDW-Multifractal bases not only on the distance between the estimated and known values in a given neighborhood, but makes an adjustment by a power law related to the data set fractal dimension (Cheng, 2000; Robinson Jr. et al., 2004).

This interpolator takes into account not only the spatial association, but also local singularities of the data by assigning significant weights to extreme values of the original dataset, so that the surfaces interpolated maintain the local variability of the data, without the smoothing of anomalous values, focus of geochemistry exploration (Robinson Jr. et al., 2004).

The geochemical maps of $\mathrm{Co}$ and Ni were interpolated on a regular grid with cells of $500 \mathrm{~m}$ using GeoData Analysis System (GeoDAS) (Cheng, 2000), with a minimum of three samples within a radius of $10 \mathrm{~km}$ (Andrade, 2008). The interpolated geochemical surfaces used in the construction of nickel prospectivity model in the NBMB are shown in Figures 4 and 5.

\section{NICKEL PROSPECTIVITY MODEL BASED ON FUZZY LOGIC}

Fuzzy logic is an adaptation of boolean logic. In boolean logic, the process of assigning weights to different evidence regarding the presence or absence of a phenomenon is respectively based on the values 0 or 1. In fuzzy logic, these values, called fuzzy possibility or relevance, are fractional and vary between 0 for absence and 1 for the potential presence of the phenomenon. Intermediate values mean different degrees of possibility of whether or not 


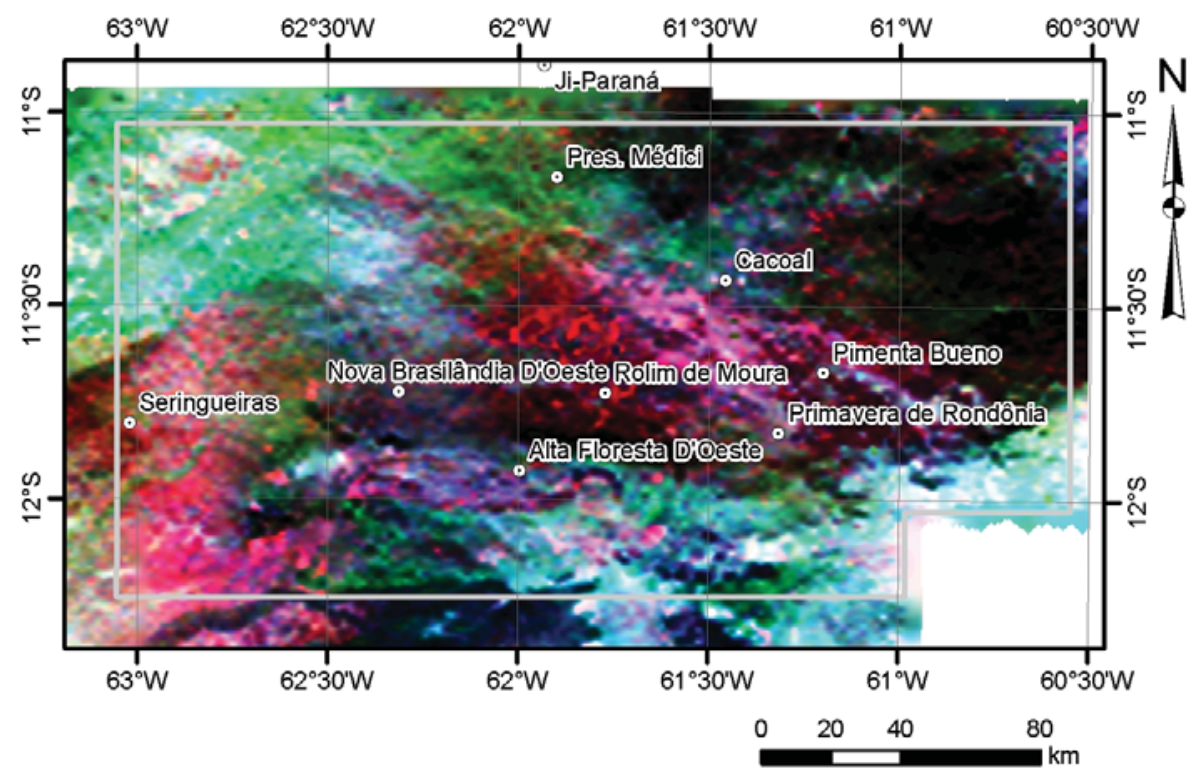

\section{Legend \\ Ternary composition in false \\ color using the CMY color pattern for $\mathrm{K}$, Th and $\mathrm{U}$ channels}

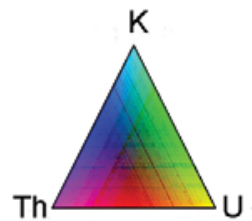

Study area limit

C City

Figure 3 - Ternary composition in false color using the CMY color pattern for K, Th and U channels. The chosen composition allows better visualization of correspondence between the geological units and their gammaspectrometric responses.

the phenomenon (eg, mineral deposit) (Bonham-Carter, 1994; Harris et al., 2001; Nóbrega, 2001; Porwal et al., 2003; Nykanen \& 0jala, 2007; Carrino et al., 2011; Magalhães \& Souza Filho, 2012; Silva et al., 2012).

In addition to greater flexibility in the weights defining, fuzzy logic has a wider range of operators (Bonham-Carter, 1994). The AND and $\mathbf{O R}$ operator keeps respectively the smallest and largest values from fuzzy possibility of evidence involved. The Fuzzy Algebraic Product is a multiplicand between the fuzzy possibilities of various evidence, resulting in decreased fuzzy possibility, but, unlike the AND operator, all evidence must participate. The Fuzzy Algebraic Sum is calculated as the difference between the unit and the mutiplicand of the differences between the unit and the fuzzy possibilities of combined evidence, which always generates an increase in the fuzzy possibility and has the contribution of all the evidence. The Gamma Fuzzy operator makes combination between the Fuzzy Algebraic Product and Fuzzy Algebraic Sum, where a weight ratio $\gamma$ is determined by the expert with a value between 0 and 1 , or favoring the effect of the product or the effect of increasing the sum.

Fuzzy logic, therefore, is considered a more malleable form to integrate and model geological data. This flexibility is ideal for the phenomena associated with mineral deposits the formation in areas where such deposits are not known. In this case, the effectiveness of the models depends on the degree of expert's knowledge on the type of deposit prospected.

In fuzzy logic modelling, the expert functions, according to the prospective model chosen, are: (i) assign, in each of the information plans (or evidences) as geological map and geophysical or geochemical surface, different fuzzy possibility classes and (ii) determine which fuzzy operators will be used in information plans integration.

The fuzzy possibility assignment to data is made in two approaches. In categorical data approach, like lithological map, classes in the information layer have not numerical meaning, so to each class (lithology), the expert determines a specific fuzzy 

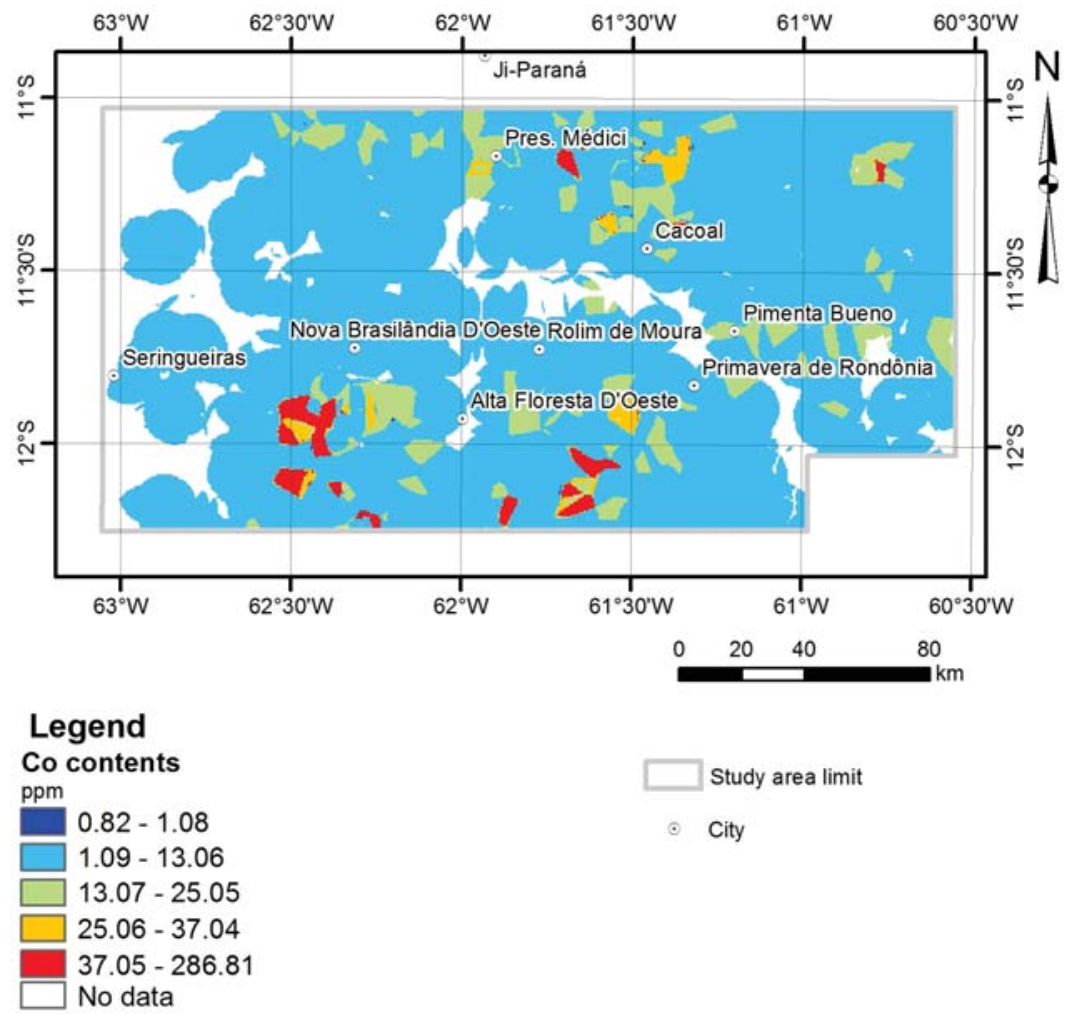

Figure 4 - Co contents in stream sediments geochemical map. The surface presented was interpolated using the IDW-Multifractal (Andrade, 2008).
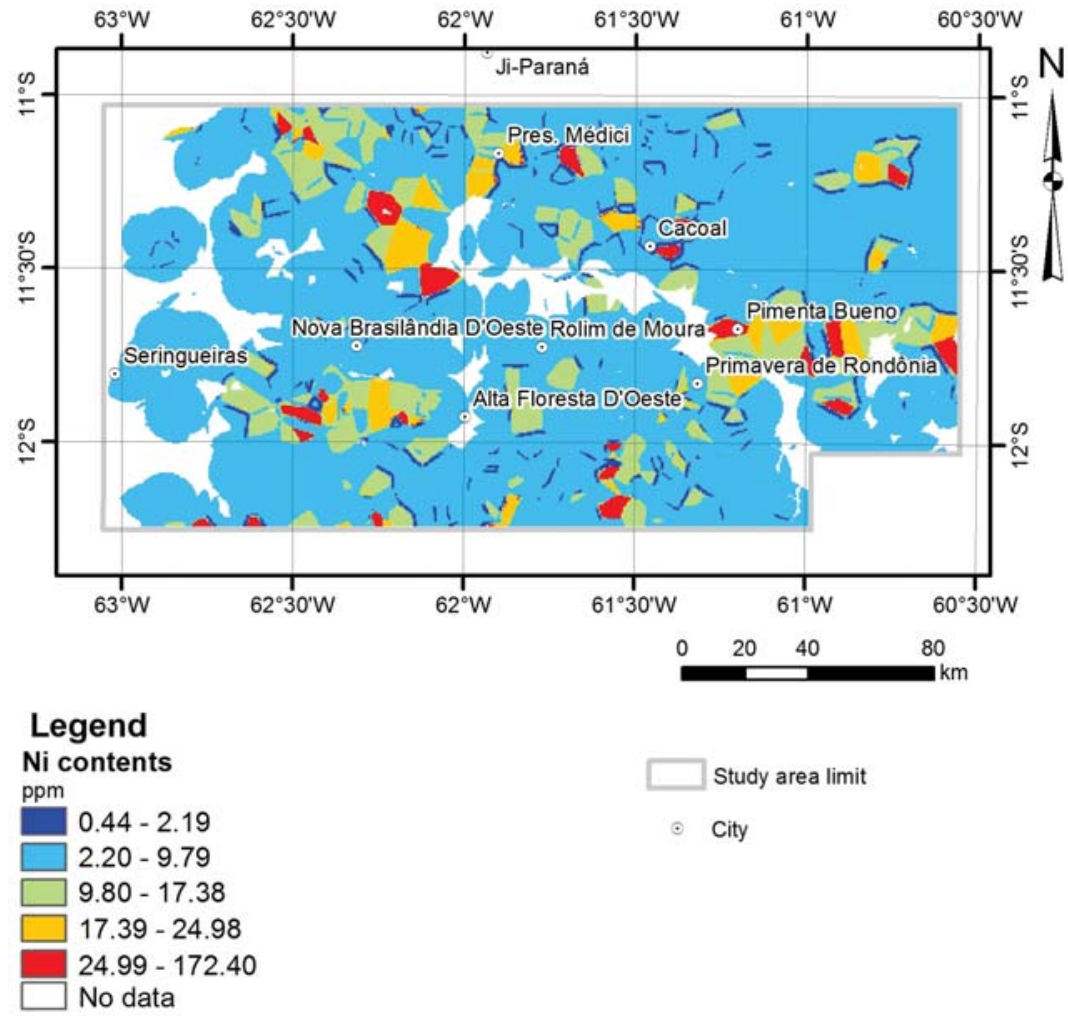

Figure $\mathbf{5}$ - Ni contents in stream sediments geochemical map. The surface presented was interpolated using the IDW-Multifractal (Andrade, 2008). 
possibility. In numerical data approach, like geochemical and geophysical maps, information plans represent numeric values, and the assign of fuzzy possibilities can be done following specific functions.

In this work, the following information plans were used to design a nickel prospectivity model in NBMB based on fuzzy logic: lithological map, analytic signal amplitude image, gammaspectrometric images of $\mathrm{K}$, Th and $\mathrm{U}$ channels and interpolated surfaces of $\mathrm{Co}$ and $\mathrm{Ni}$ contents in stream sediments interpolated by IDW-Multifractal. The modelling was conducted in ArcGIS software, developed by Environmental Systems Research Institute (ESRI), using Spatial Data Modeller (Arc-SDM) extension (Sawatzky et al., 2009).

The prospective model adopted for favorable areas considers (i) the occurrence of basic and/or ultrabasic rocks, (ii) high values for analytic signal amplitude representing magnetic anomalies, (iii) low levels of gamma radiation in the channels $K$, Th and $\mathrm{U}$ and (iv) geochemical anomalies $\mathrm{Co}$ and Ni surfaces interpolated by IDW-Multifractal (Andrade, 2008).

The different lithostratigraphic units on the geological map were divided into six groups of fuzzy possibility according to Table 2. Fuzzy operators do not consider missing values and fuzzy possibility must always vary between 0 and 1 . The fuzzy possibility was considered 0 (zero) for Phanerozoic areas because in these areas, gammaspectrometry represents the responses of sedimentary rocks overlying the older units and may cover favorable areas.

Fuzzy possibilities for geophysical information plans, all of numeric nature, were defined based on Small and Large functions, which respectively assign highest fuzzy possibility to lower and higher values in the information plan. Small and Large functions are shown respectively in Equation 1 and Equation 2, where $\mu(x)$ is the fuzzy possibility, $x$ represents determined value information layer, $M$ is the midpoint and $S$ is the spreading. The constant $b$ equals 0 for information plan with non-negative numerical data or equal to the minimum value for information plans containing negative values.

$$
\begin{gathered}
\mu_{(x)}=\frac{1}{1+((x-b) / M)^{S}} \\
\mu_{(x)}=\frac{1}{1+((x-b) / M)^{-S}}
\end{gathered}
$$

Both functions assign fuzzy possibility near 0.5 to values concentrated around a midpoint, defined by the expert, which also determines spreading value used in the functions. The larger the spreading, the more abrupt transition between lower and higher values than the midpoint.
The analytic signal amplitude image was first converted to 8 bits resolution. Fuzzy possibilities for this information layer was defined based on Large function, with midpoint at 150, spreading equal ro 5 and 'b' constant equal to 0 (Fig. 6). Large function was chosen by assigning high values of fuzzy possibility to magnetic anomalies, according the prospective model proposed.

Fuzzy possibilities for gammaspectrometry images were defined based on Small functions, with midpoints at 18 for K, 19 for 12 for Th and $U$, scatterings of 7 and ' $b$ ' constants equal to 12 for $\mathrm{K}, 21$ for Th and 13 for U. Figure 6 shows functions graphics applied to gammaspectrometric data. Small function was chosen for ability to assign higher values of the fuzzy possibilities to areas with low values of gamma radiation for the three channels.

Fuzzy possibilities for geochemical information plans were defined based on the Linear function in Arc-SDM. This feature gives the fuzzy possibility respectively equal to 0 or 1 for values smaller or larger than some minimum or maximum values defined by the expert and also distribute linearly fuzzy possibility values between 0 and 1 to values between the minimum and maximum set.

Equation 3 gives the Linear function used in defining fuzzy possibilities to geochemical data, where $\mu(x)$ is the fuzzy possibility, $x$ represents determined value information layer and $m$ and $M$ are respectively the minimum and maximum values defined by the expert.

$$
\begin{aligned}
& \mu_{(x)}=0 \text { to } x \leq m ; \mu_{(x)}=1 \text { to } x \geq M ; \text { and } \\
& \mu_{(x)}=(M-m)^{-1} \cdot x-m /(M-m)
\end{aligned}
$$

For both geochemical maps ( $\mathrm{Co}$ and $\mathrm{Ni}$ ), the fuzzy possibilities were defined based on Linear functions, using as a minimum threshold values between background and 1st order anomaly (98 ppm Co and 15 ppm Ni) and maximum thresholds values between 1st and 2nd orders anomalies (199 ppm for Co and 104 ppm for Ni), defined in Andrade (2008). The functions graphics used are shown in Figure 7.

Defined the fuzzy possibilities for all information plans, these were combined using various fuzzy logic operators. Figure 8 illustrates the flowchart of fuzzy modelling described below.

The fuzzy possibility maps of gammaspectrometric data were combined using the FUZZY PRODUCT, generating a Gammaspectrometric Fuzzy Map. This map, was then combined with the fuzzy possibility of analytic signal amplitude map using FUZZY SUM operator, resulting in Geophysical Fuzzy Map.

The fuzzy possibilities maps of geochemical data ( $\mathrm{Co}$ and $\mathrm{Ni}$ ) were combined through FUZZY SUM, resulting in Geochemical Fuzzy Map. 
Table 2 - Fuzzy possibilities assignment to lithostratigraphic units.

\begin{tabular}{|c|c|c|}
\hline Lithostratigraphic units & Fuzzy possibility & Justifying \\
\hline $\begin{array}{c}\text { Rio Branco Formation and } \\
\text { Alta Floresta Intrusive Suit }\end{array}$ & 0.9 & Basic rocks associated to NBMB \\
\hline Cacoal Intrusive Suit & 0.7 & Other basic to ultrabasic rocks \\
\hline Migrantinópolis Formation & 0.5 & $\begin{array}{c}\text { Metasedimentary rocks with basic } \\
\text { intrusions associated to NBMB }\end{array}$ \\
\hline Palmeiral and Dardanelos formations & 0.3 & Other metasedimentary rocks \\
\hline $\begin{array}{c}\text { Jamari Complex, Roosevelt Group, } \\
\text { Serra da Providência, São Romão, } \\
\text { Costa Candeias, Rio Pardo and }\end{array}$ & 0.1 & $\begin{array}{c}\text { Gneisses, granitoids and } \\
\text { acid vulcanis rocks }\end{array}$ \\
\hline $\begin{array}{c}\text { Primavera Group and } \\
\text { lateritic-detritus covers }\end{array}$ & 0 & $\begin{array}{c}\text { Phanerozoic units which may or } \\
\text { may not cover favorable areas }\end{array}$ \\
\hline
\end{tabular}

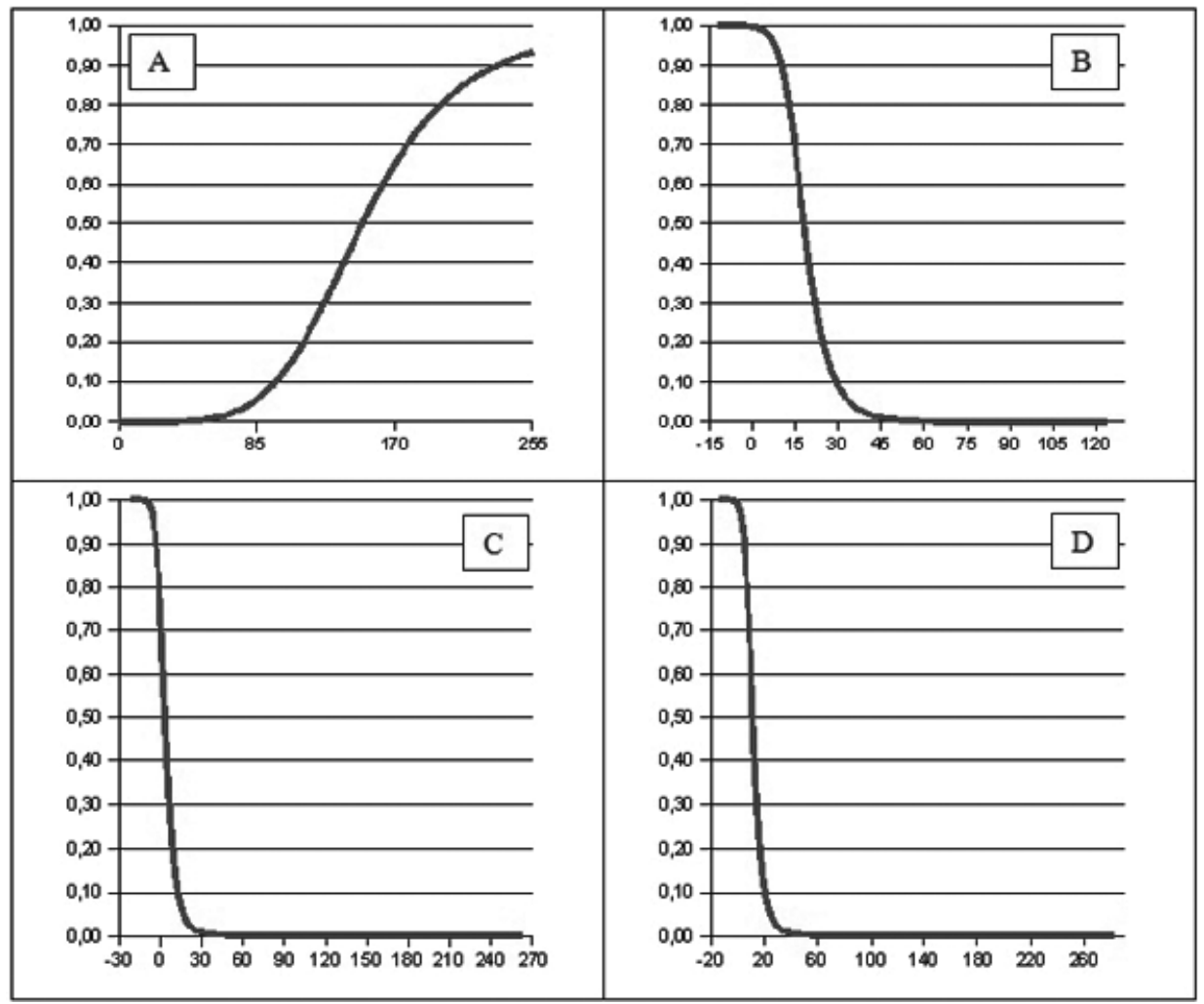

Figure 6 - Functions used in assigning fuzzy possibilities for geophysical maps. Graphs: (A) Large Function used to assign fuzzy possibilities for ASA map. (B) Small Function used to assign fuzzy possibilities for K gammaspectrometric map. (C) Small Function used to assign fuzzy possibilities for Th gammaspectrometric map. (D) Small Function used to assign fuzzy possibilities for $\mathrm{U}$ gammaspectrometric map.

The Lithological Fuzzy Map resulted from the fuzzy possibilities assigning for map lithological map.

The Geophysical and Lithologic fuzzy maps were combined using the FUZZY SUM operator. The resulting fuzzy map of this sum was also combined with Geochemical Fuzzy Map through FUZZY SUM, resulting in Nickel Prospectivity Map for NBMB, which was reclassified into five classes of Ni prospectivity: High, with values between 0.85 and 1.00; Intermediate to High, with 


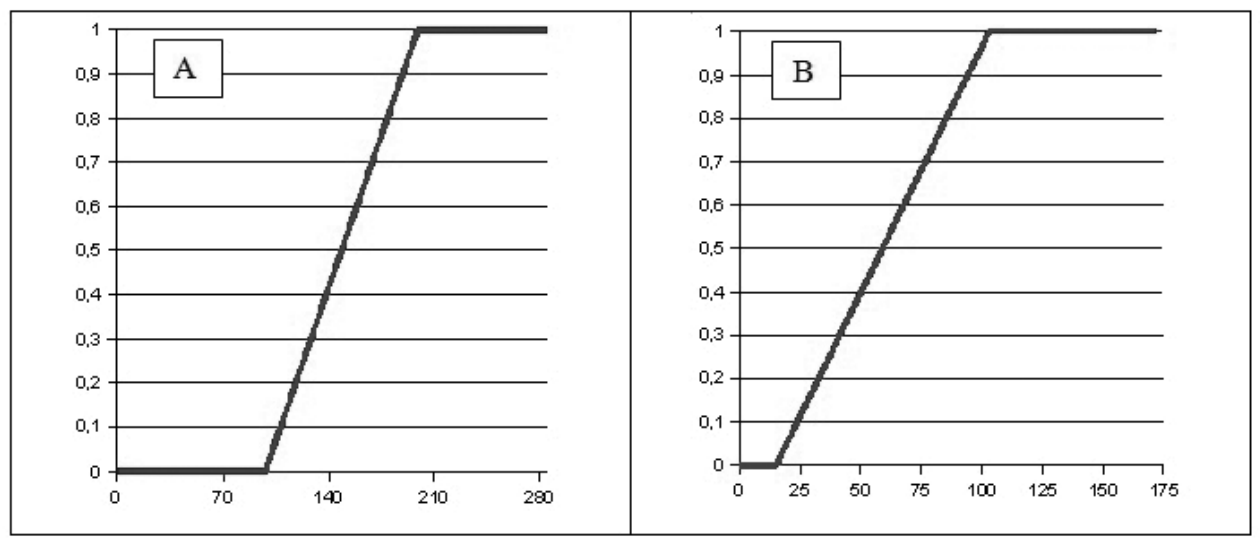

Figure 7 - Functions used in assigning fuzzy possibilities for geochemical maps. Graphs: (A) Linear Function used to assign fuzzy possibilities for Co contents map. (B) Linear Function used to assign fuzzy possibilities for Ni contents map.

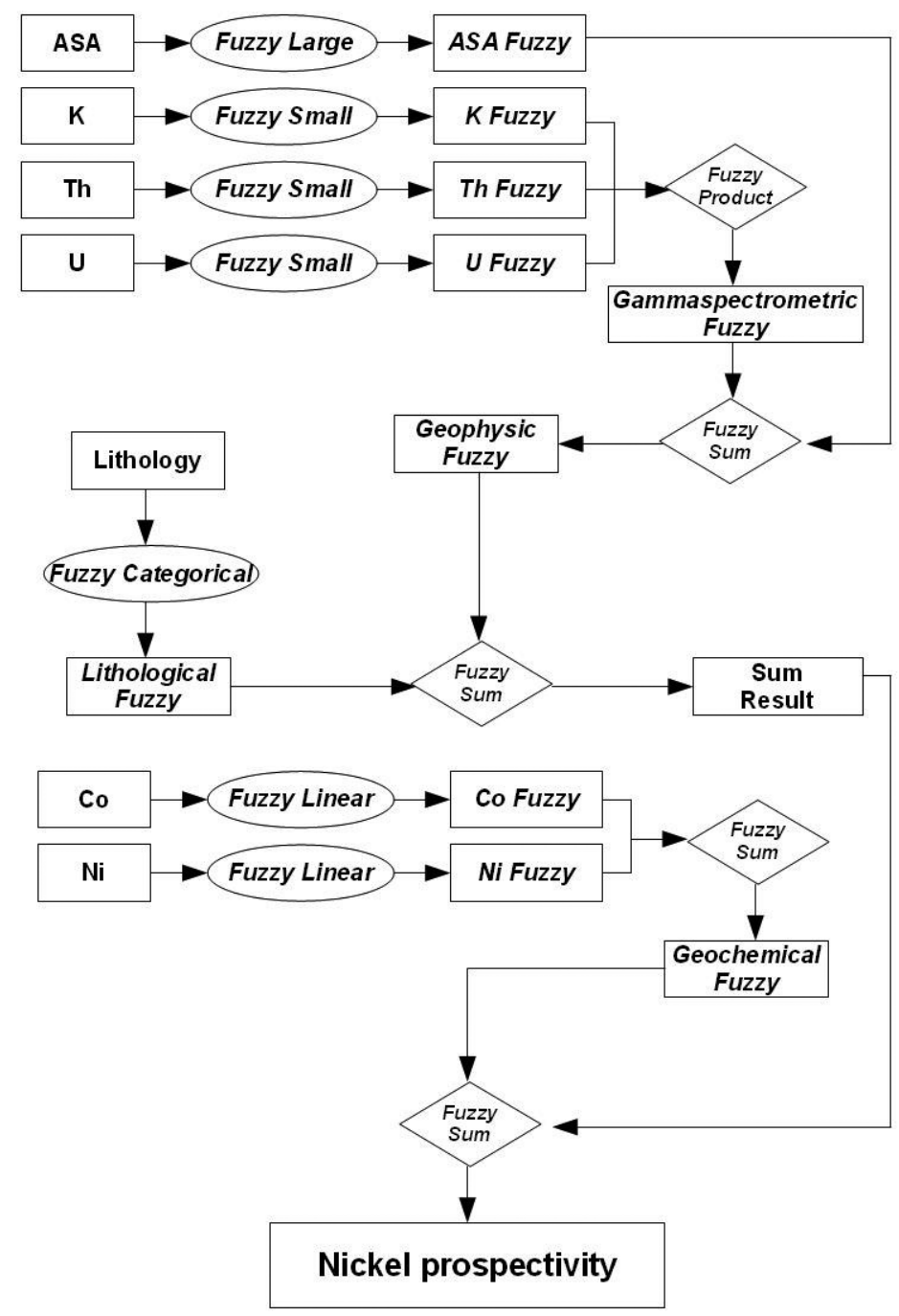

Figure 8 - Flowchart of fuzzy modelling for Ni prospectivity on NBMB. 


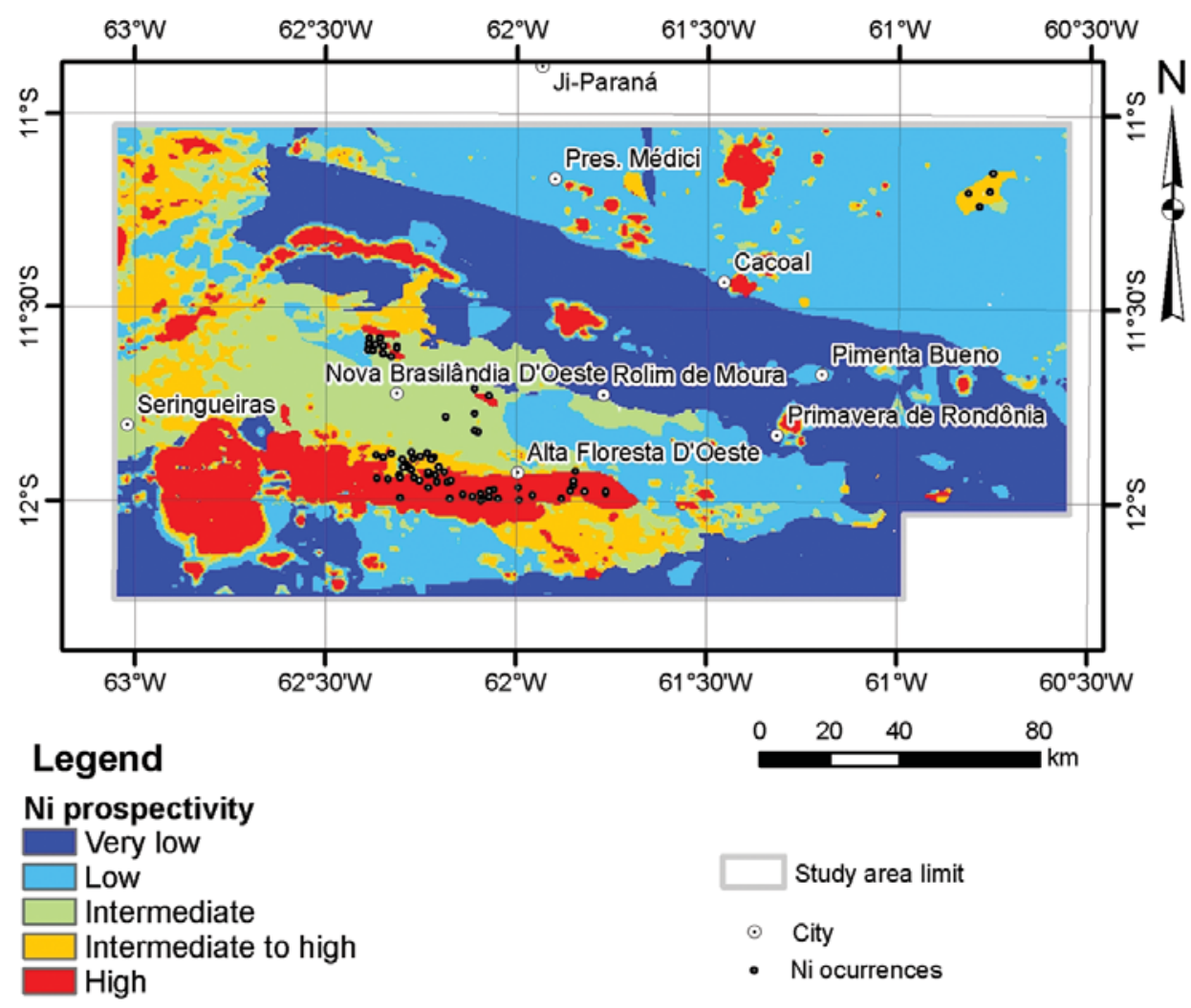

Figure $\mathbf{9}$ - Nickel Prospectivity Map for NBMB. Note that most of the Ni occurrences indexed by CPRM are located in high Ni prospectivity areas or very close to them.

values between 0.60 and 0.84 ; Intermediate, with values between 0.40 and 0.59 ; Low, with values between 0.10 and 0.39 ; and Very Low, with values between 0.00 and 0.09 (Fig. 9).

\section{RESULTS AND DISCUSSION}

In the nickel prospectivity map shown in Figure 9, considering the 76 occurrences of Ni registered by CPRM, 49\% are located in areas with high nickel prospectivity, $16 \%$ in areas with intermediate to high nickel prospectivity, $26 \%$ in areas with intermediate prospectivity and $9 \%$ in areas with low nickel prospectivity.

These occurrences are mostly anomalous Ni contents in samples of stream sediments. Therefore, it is acceptable that there is an offset between the occurrence and its source area, as in the case of occurrences situated North to the Rio Branco Formation, a high nickel prospectivity area.

There are also areas with high nickel prospectivity where $\mathrm{Ni}$ occurrences cataloged by CPRM are not observed. In these areas, where the occurrence coincides with lithostratigraphic units of basic or ultrabasic nature, Ni occurrences may not exist or have not been identified by regional prospecting campaigns. But when such areas are related to magnetic anomalies covered by Phanerozoic rocks or sediments, Ni occurrences cannot be identified based on surface prospection, but only in drilling campaigns.

The distribution of the areas with high nickel prospectivity on the developed model is mainly determined by the presence of strongly magnetic bodies, with high values of analytic signal amplitude, and lithostratigraphic units composed by basic or ultrabasic rocks (Figs. 1, 2 and 9). This distribution is consistent with the adopted fuzzy logic model.

Regarding magnetic bodies, the assignment of fuzzy possibility to analytical signal amplitude used Large function, giving greater fuzzy possibilities to high values of analytical signal amplitude related to these bodies. Combining this information plan with gammaspectrometric layers through FUZZY SUM resulted in a Geophysical Fuzzy Map where fuzzy possibilities were controlled predominantly by aeromagnetic data.

In the case of lithostratigraphic units, were assigned high fuzzy possibility values ( $\geq 0.7$ ) for Rio Branco Formation, Alta Floresta Intrusive Suit and Cacoal Intrusive Suit, where basic or ultrabasic rocks dominate. Combining this information pan with the Geophysical Fuzzy Map through FUZZY SUM resulted in a 
map in which the largest fuzzy possibilities were then determined by the occurrence of magnetic bodies and/or basic or ultrabasic lithostratigraphic units.

Because high spatial correlation between $\mathrm{Co}$ and $\mathrm{Ni}$ geochemical and basic or ultrabasic lithostratigraphic units distribution (Figs. 1, 4 and 5), combination of Geochemical Fuzzy Map by Fuzzy Sum with the result of the FUZZY SUM of Geophysical Fuzzy Map and Lithologic Fuzzy Map gave little influence of geochemical data on the final model.

\section{CONCLUSIONS}

The growing demand for minerals goods stimulates the creation of new techniques that can help mineral exploration, as tools for modelling and mapping mineral prospectivity in GIS environment, such those presented in this paper.

Mineral potential in Amazon region is still poorly understood and exploited. The Amazonian craton, one of the largest cratonic entities in the world, home to several world-class deposits in the Carajás region. However, in other areas like in NBMB in SW Amazonian craton, significant mineral deposits are not yet known. In these areas, regional prospecting techniques can assist the work of exploration geologists in the arduous task of finding economically viable mineral deposits.

Mineral potential in GIS mapping represents a way to integrate and model geological data to determine areas favorable to the occurrence of mineral deposits.

The knowledge-driven approach given to nickel prospectivity modelling and mapping in NBMB by fuzzy logic, based on lithological, geophysical and geochemical criteria, showed consistent results in locating areas with high Ni potential, when compared with Ni occurrences cataloged by CPRM.

Modelling results invariably depend on the scale and resolution of the data. In this study, we used appropriate data to 1:500,000 scale. Thus, the results represent potential for regional exploration and cannot be used, for example, to locate drillholes, but are useful for defining areas to more detailed prospection.

\section{REFERENCES}

ANDRADE LB. 2008. Mapeamento do potencial mineral para níquel e ouro no Cinturão Metassedimentar Nova Brasilândia - Rondônia por meio de lógica nebulosa (fuzzy) e redes neurais artificiais. Master dissertation on Geosciences, Post-graduate Program in Geosciences, Instituto de Geociências, Universidade Estadual de Campinas, 69 pp.

BLUM MLB. 1999. Processamento e Interpretação de Dados de Geofísica Aérea no Brasil Central e sua Aplicação à Geologia Regional e à
Prospecção Mineral. Doctorate thesis on Geology, Post-graduate Program in Geology, Instituto de Geociências, Universidade de Brasília, $229 \mathrm{pp}$.

BONHAM-CARTER GF. 1994. Geographic Information Systems for Geoscientists: Modelling with GIS. Pergamon Press, Ontario, 398 pp.

BONHAM-CARTER GF. 1997. GIS Methods for Integrating Exploration Data Sets. In: Exploration 97: Decennial International Conference On Mineral Exploration, 4., 1997, Toronto. Proceedings. Toronto: Prospectors and Developers Association of Canada, p. 59-64.

CARRINO TA, SILVA AM, BOTELHO NF \& SILVA AAC. 2011. Análise prospectiva para ouro nas regiões Ouro Roxo-Cantagalo e Chico Torres, Província Mineral do Tapajós. Brazilian Journal of Geophysics, 29(1): 135-154.

CHENG Q. 1999. Multifractality and spatial statistics. Computer \& Geosciences, 25(9): 949-961.

CHENG Q. 2000. GeoData Analysis System (GeoDAS) for Mineral Exploration: User's Guide and Exercise Manual. York University, Toronto, $204 \mathrm{pp}$.

HARRIS JR, WILKINSON L, HEATHER K, FUMERTON S, BERNIER MA, AYER J \& DAHN R. 2001. Application of GIS Processing Techniques for producing mineral prospectivity maps - A case study: Mesothermal $\mathrm{Au}$ in the Swayze Greenstone Belt, Ontario, Canada. Natural Resources Research, 10(2): 91-124.

KLOOSTERMAN JB. 1968. Uma província do tipo nigeriano no sul da Amazônia. Revista de Engenharia, Mineração Metalurgia, 47(278): 5964.

LI C, MA T \& CHENG J. 2004. A fractal interpolation approach to geochemical exploration data processing. Mathematical Geology, 36(5): 593-606.

LINS CAC. 2003. Manual Técnico da Área de Geoquímica. CPRM, Rio de Janeiro, 35 pp.

MAGALHÃES LA \& SOUZA FILHO CR. 2012. Targeting of Gold Deposits in Amazonian Exploration Frontiers using Knowledge- and Data-Driven Spatial Modelling of Geophysical, Geochemical and Geologic Data. Surveys in Geophysics, 33: 211-241.

MINTY BRS. 1991. Simple micro-levelling for aeromagnetic data. Exploration Geophysics, 22: 591-592.

NÓBREGA RP. 2001. Análise espacial 'knowledge-driven'e 'data-driven': 0 uso das lógicas boolena, fuzzy e redes neurais para geração de mapas de favorabilidade mineral na região centro-leste da Bahia. Master dissertation on Geosciences, Post-graduate Program in Geosciences, Instituto de Geociências, Universidade Estadual de Campinas, 72 pp.

NYKANEN VM \& OJALA VJ. 2007. Spatial analysis techniques as successful mineral-potential mapping tools for orogenic gold deposits in the northern Fennoscandian shield, Finland. Natural Resources Research, 16(2): 85-92. 
PINTO FILHO FP. 1977. Projeto Sudeste de Rondônia. CPRM, Rio de Janeiro, $100 \mathrm{pp}$.

PORWAL A, CARRANZA EJM \& HALE M. 2003. Knowledge-driven and data-driven fuzzy models for predictive mineral potential mapping. Natural Resources Research, 12(1): 1-25.

RIZZOTTO GJ. 1999. Petrologia e Ambiente Tectônico do Grupo Nova Brasilândia - R0. Master dissertation on Geosciences, Post-graduate Program in Geosciences, Instituto de Geociências, Universidade Federal do Rio Grande do Sul. 136 pp.

RIZZOTTO GJ. 2001. Reavaliação do Ciclo Orogênico Sunsás/Aguapeí no Sudoeste do Cráton Amazônico. In: Workshop Geology of the SW Amazonian Craton: State-of-the-Art, 2001, São Paulo. Extended Abstracts, São Paulo: IGC-USP, p. 66-70.

RIZZOTTO GJ, SCANDOLARA JE \& ADAMY A. 2000. Geologia e Geomorfologia dos Municípios de Alta Floresta e Alto Alegre dos Parecis. Porto Velho. CPRM. 64 pp.

ROBINSON Jr GR, KAPO KE \& GROSSMAN JN. 2004. Chemistry of stream sediments and surface waters in New England. Available on: <http://pubs.usgs.gov/of/2004/1026/>. Access on: January 15, 2013.

SANTOS JOS. 2003. Geotectônica dos Escudos das Guianas e BrasilCentral. In: BIZZI LA, SCHOBBENHAUSC, VIDOTTI RM \& GONÇALVES JH (Eds.). Geologia, Tectônica e Recursos Minerais do Brasil. Brasília, CPRM, p. 169-226.

SCANDOLARA J. 1999. Geologia e Recursos Minerais do Estado de Rondônia: Texto Explicativo e Mapa Geológico do Estado de Rondônia. Porto Velho, CPRM, $97 \mathrm{pp}$.

SCHOBBENHAUSC, GONÇALVESJH, SANTOS JOS, ABRAM MB, LEÃO NETO R, MATOS GMM, VIDOTTI RM, RAMOS MAB \& JESUS JDA.
2004. Carta Geológica do Brasil ao Milionésimo, Sistema de Informações Geográficas - SIG e 46 folhas na escala 1:1.000.000. Brasília, CPRM. 41 CD-ROM.

SILVA EC, SILVA AM, TOLEDO CLB, MOL AG, OTTERMAN DW \& SOUZA RC. 2012. Mineral Potential Mapping for Orogenic Gold Deposits in the Rio Maria Granite Greenstone Terrane, Southeastern Pará State, Brazil. Economic Geology and the Bulletin of the Society of Economic Geologists, 107: 1387-1402.

SAWATZKY DL, RAINES GL, BONHAM-CARTER GF \& LOONEY CG. 2009. Spatial Data Modeller (SDM): ArcMAP 9.3 geoprocessing tools for spatial data modelling using weights of evidence, logistic regression, fuzzy logic and neural networks. ArcSDM Manual. Available on: $<$ http://www.ige.unicamp.br/sdm/ArcSDM10/source/ReadMe.pdf>.

Access on: January 17, 2013.

TEIXEIRA W \& TASSINARI CCG. 1984. Caracterização geocronológica da província Rondoniana e suas implicações geotectônicas. In: Symposium Amazônico, 2., 1984, Manaus. Proceedings... Manaus: SBG Núcleo Norte, p. 175.

TOHVER E, VAN DER PLUIJM B, MEZGER K, ESSENE E, SCANDOLARA J \& RIZZOTTO GJ. 2004. Significance of the Nova Brasilândia metasedimentary belt in western Brazil: Redefining the Mesoproterozoic boundary of the Amazon craton. Tectonics, 23: 1-20.

TOHVER E, VAN DER PLUIJM B, MEZGER K, SCANDOLARA J \& ESSENE E. 2005. Two stage tectonic history of the SW Amazon Craton in the late Mesoproterozoic: identifying a cryptic suture zone. Precambrian Research, 137(1): 35-59.

Recebido em 11 julho, 2013 / Aceito em 13 fevereiro, 2014

Received on July 11, 2013 / Accepted on February 13, 2014

\section{NOTES ABOUT THE AUTHORS}

Lucas Barros de Andrade. Geologist from Universidade de Brasília (UnB, 2003), Geoprocessing Specialist from the same institution in 2003 and M.Sc. in Geosciences from the Universidade Estadual de Campinas (UNICAMP, 2008). Currently, serves as Federal Forensic Expert in Departamento de Polícia Federal (Brazilian Federal Police Department), working in areas as geographic information systems (GIS), digital image processing, remote sensing and geophysics, especially in forensic application of these technologies.

Adalene Moreira Silva. Geologist Engineer from Universidade Federal de Ouro Preto (UFOP, 1989), M.Sc. and Ph.D. in Geology from UnB (1992 and 1999 , respectively). Professionally, worked as researcher in United States Geological Survey (1997-1999), Visiting Professor at UnB (2000-2002), Post-doctoral research (05/2002-04/2003) and Professor (04/2003-10/2005) at the Institute of Geosciences of UNICAMP. Currently, works in UnB and develops main projects on new processing, interpretation and data integration applied to mineral exploration, geological mapping and crustal evolution.

Carlos Roberto de Souza Filho. Geologist Engineer from Universidade Federal de Ouro Preto (UFOP, 1988). Holds a Masters in Metallogenesis (UNICAMP, 1991); Ph.D. in Earth Sciences and Remote Sensing (Open University, England, 1995); Young-Research Fellowship (FAPESP-UNICAMP, 1995-1997); Assistant-Professorship (UNICAMP, 1997-2002); and Associate-Professorship (UNICAMP, 2002-2008). Currently, is a Full Professor at the Geology and Natural Resources Department of the Geosciences Institute (IG) of UNICAMP and leader of the Geotechnology Research Group. Is also a CNPq Researcher (level 1A) and responsible for several research laboratories, including those related to infrared reflectance and emissivity spectroscopy, remote sensing and digital image processing; GIS and data integration. Is a NASA researcher for the ASTER, Mars-Earth Analogs and HyspIRI programs. Presently contributes with the editorial board of numerous international journals, including the International Journal of Applied Earth Observation and Geoinformation and Mathematical Geosciences. 